\title{
PERANCANGAN OUTSOURCE MANAGEMENT SYSTEM BERBASIS WEB PADA PT. SIGMA CIPTA UTAMA
}

\author{
Muhammad Iqbal ${ }^{1}$, Redo Abeputera Sihombing ${ }^{2}$, Halimatusha'diah ${ }^{3}$ \\ Program Studi Informatika, Fakultas Teknik dan Ilmu Komputer, Universitas Indraprasta PGRI \\ Jalan Raya Tengah No 80, Kelurahan Gedong, Pasar Rebo, Jakarta Timur \\ iqbalmuhammad9321@gmail.com ${ }^{1}$, redounindra@gmail.com² ${ }^{2} \underline{\text { halimah3186@gmail.com }}^{3}$
}

\begin{abstract}
Abstrak
Pesatnya kemajuan teknologi yang semakin canggih pada saat ini akan mendorong manusia untuk mencari kemudahan dan membantu dalam mendapatkan suatu informasi yg cepat, tepat dan akurat. Adapun tujuan penelitian ini untuk mendapatkan laporan yang efisien dan akurat sehingga dengan adanya sistem laporan outsourcing management system tidak memungkinkan terjadinya duplikasi data dan kesalahan input. Penelitian ini bertujuan untuk membantu mengadakan sistem terkomputerisasi dengan menggunakan metode grounded. Metode tersebut dipilih karena mampu melakukan penelitian berdasarkan yang ada di lapangan dan menggunakan analisis perbandingan. Maka metode grounded cocok diimplementasikan pada perancangan outsource management system berbasis web. Hasil penelitian yang di buat oleh peneliti ini sangat membantu untuk pengelolaan data karyawan outsourcing pada PT Sigma Cipta Utama.
\end{abstract}

Kata Kunci: perancangan, outsource management system, berbasis web.

\begin{abstract}
The rapid advancement of technology that is increasingly sophisticated at this time will encourage human beings to seek ease and assist in obtaining an information that is fast, precise and accurate. The purpose of this research is to obtain an efficient and accurate report so that with the system of outsourcing management system report does not allow the occurrence of data duplication and input errors. This research aims to help conduct a computerized system using the grounded method. The method is chosen because it is capable of conducting research based on the field and using comparative analysis. Then the suitable grounded method is implemented in the design of outsource management system Web-based. The results of the research made by this researcher are very helpful for the management of outsourcing employee data on PT Sigma Cipta Utama.
\end{abstract}

Keywords: design, outsource management system, web-based.

\section{PENDAHULUAN}

\section{Latar Belakang Masalah}

Pesatnya kemajuan teknologi yang semakin canggih pada saat ini akan mendorong manusia untuk mencari kemudahan dan membantu dalam mendapatkan suatu informasi yang cepat, tepat dan akurat. Perancangan merupakan perancangan yang sesungguhnya merupakan suatu aktivitas rekayasa perangkat lunak yang dimaksud untuk membuat keputusan-keputusan utama seringkali bersifat struktural (Pressman, 2010). Sistem adalah rangkaian dari dua atau lebih komponen-komponen yang saling berhubungan, yang berinteraksi untuk mencapai suatu tujuan. Sebagian besar sistem terdiri dari subsistem yang lebih kecil yang mendukung sistem yang lebih besar (Diana \& Setiawati, 2011).

Sistem merupakan serangkaian bagian yang saling tergantung dan bekerja sama untuk mencapai tujuan tertentu (Marshall B. Romney \& Steinbart, 2003). Sistem adalah suatu jaringan prosedur yang dibuat menurut pola yang terpadu untuk melaksanakan kegiatan pokok perusahaan (Mulyadi, 2016). outsourcing dapat didefinisikan sebagai pembuatan kontrak dengan pihak ketiga sebagai pemberi layanan pengelolaan dan penyelesaian sejumlah pekerjaan, dalam jangka waktu biaya, dan tingkat layanan tertentu (Oshri et al., 2009). Management berasal dari kata to manage yang artinya mengatur. Adapun unsur-unsur manajemen yang terdiri dari 6M yaitu man, money, methode, machines, materials, dan market. Management adalah suatu cara/seni mengelola sesuatu untuk dikerjakan oleh orang lain. Untuk mencapai tujuan tertentu secara efektif dan efisien yang bersifat masif, kompleks dan bernilai tinggi tentulah sangat dibutuhkan management. Manajemen adalah ilmu dan seni mengatur proses proses pemanfaatan sumber daya manusia dan sumber-sumber lainnya secara efektif dan efisien untuk mencapai suatu tujuan tertentu (Malayu S.P Hasibuan, 2012). Diagram Aliran Data merupakan suatu penggambaran model yang memungkinkan profesional sistem untuk 
menggambarkan sistem sebagai suatu susunan proses yang dihubungkan satu sama lain dengan alur data, baik secara manual maupun terkomputerisasi.

Diagram Alir Data adalah sebuah alat yang menggambarkan aliran data dan sampai sebuah sistem selesai, dan kerja atau proses dilakukan dalam sistem tersebut (Indrajani, 2014). Data Flow Diagram atau dalam bahasa indonesia menjadi Diagram Alir Data (DAD) adalah referesentasi grafik yang menggambarkan aliran informasi dan transformasi informasi yang diaplikasikan sebagai data yang mengatur dari masukan (input) dan keluaran (output). DFD tidak sesuai untuk memodelkan sistem yang menggunakan pemrograman berorientasi objek (Sukamto\&Shalahuddin, 2016). Kemajuan teknologi dapat mendukung suatu pengolahan informasi menjadi pemicu persaingan dunia bisnis dan ekonomi yang semakin kompetetif. Kemajuan teknologi dan informasi terutama dalam bidang komputerisasi akan sangat membantu dalam pemecahan masalah dalam melakukan suatu proses pekerjaan terutama dalam pengelolaan proses suatu rangkaian kerja sehingga dapat terintegrasi dengan baik, dan mengefisienkan waktu, karena hampir setiap pekerjaan dilakukan dengan terkomputerisasi.

PT. Sigma Cipta Utama dalam pengelolaan data karyawan outsourcing masih dilakukan secara manual sehingga sering terjadinya duplikasi data dan kesalahan input. Tujuan dari penelitian ini adalah untuk membantu mengatasi masalah sistem yang sedang berjalan pada PT. Sigma Cipta Utama, untuk membuat tempat penyimpanan data karyawan outsourcing yang terkomputerisasi pada PT. Sigma Cipta Utama, untuk mendapatkan laporan yang efisien dan akurat dan untuk mengurangi penumpukan arsip data karyawan outsourcing pada PT. Sigma Cipta Utama.

Manfaat yang didapat dari hasil penelitian ini adalah dengan dibangunnya aplikasi yang selama ini dilakukan secara manual menjadi sistem komputerisasi pengelolaan data karyawan outsourcing menjadi lebih efektif dan mudah dalam penggunaannya serta dapat memperoleh data karyawan outsourcing dengan lebih mudah. Selain itu manfaat yang diperoleh penelitian ini dapat membantu peneliti lainnya yang ingin melakukan penelitian dibidang yang sama.

\section{PENELITIAN RELEVAN}

Penelitian oleh Rahmat Gunawan yang berjudul Pengembangan Sistem Informasi Karyawan Berbasis Java dari Universitas Indraprasta PGRI tahun 2014. Hasil dari penelitian ini adalah membuktikan bahwa Pengembangan Sistem Informasi Karyawan Berbasis Java sangat membantu untuk mengelola data karyawan sehingga tidak harus membuka file-file hanya dengan membuka aplikasi yang sudah dibuat oleh peneliti.

\section{METODE PENELITIAN}

\section{Observasi}

Peneliti mengamati secara langsung mengenai objek dan penelitian yang sedang diamati, tepatnya dimulai pada bulan Maret 2019 sampai dengan bulan Juni 2019.

\section{Wawancara}

Dalam metode ini difokuskan kepada kebutuhan data karyawan outsourcing, termasuk bagaimana proses untuk sistem input data pada karyawan yang dikelola.

\section{Langkah-langkah Pengembangan Sistem}

Identifikasi sebuah sistem untuk kebutuhan sistem baru yang seharusnya dilakukan, tidak hanya didasarkan kebutuhan-kebutuhan konsumsi sistem saja, tetapi juga dipandang dari suatu manfaat dari aplikasi yang selama ini dibuat akan tetapi sampai saat ini tidak pernah terpenuhi. Ada beberapa metode yang dapat digunakan dalam pengembangan piranti lunak supaya bisa terstruktur, salah satunya adalah Classic Life Cycle atau lebih dikenal dengan model Waterfall.

Adapun rancangan sistem ini harus mengikuti tahapan-tahapan pada metode yang digunakan yaitu metode Waterfall yang meliputi proses-proses sebagai berikut: 


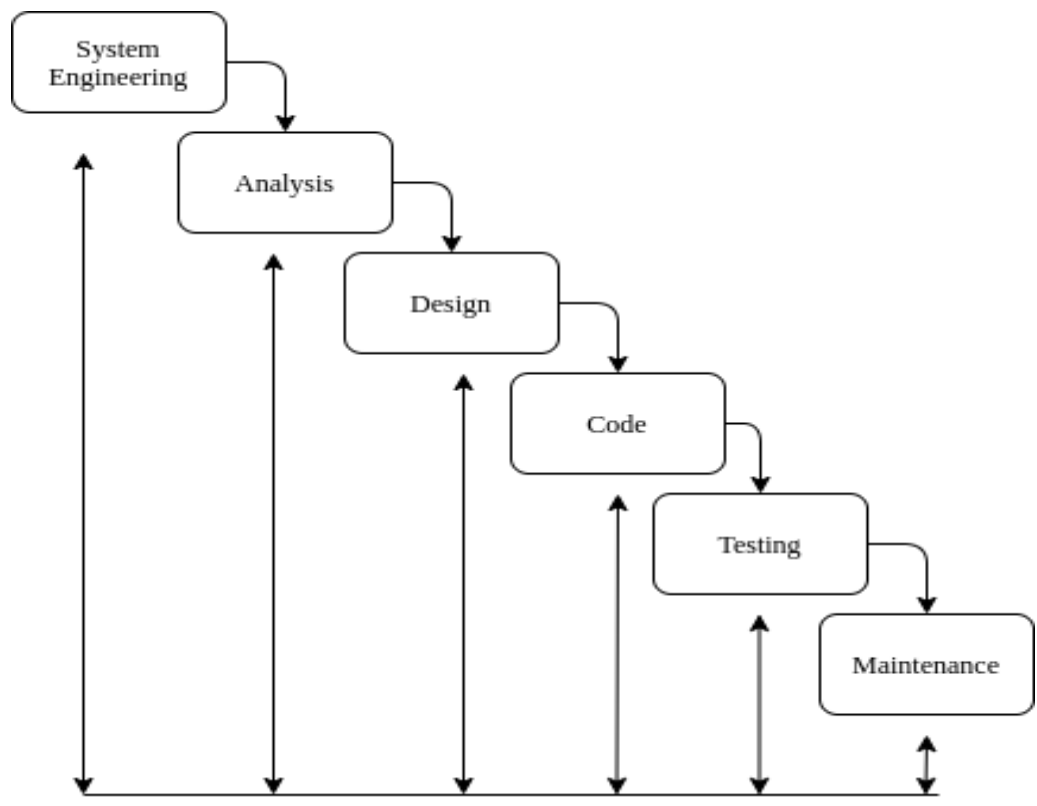

Gambar 1. Pengembangan sistem model waterfall

\section{System Engineering (Rekayasa Sistem)}

Rekayasa sistem adalah kumpulan dari suatu konsep, pendekatan, metodologi, dan alat-alat bantu untuk menginstalasi dan merancang sebuah kompleksitas sistem. Kompleksitas sistem dapat disebabkan atas dua hal, kompleksitas dinamis dan kompleksitas detail. Kompleksitas detail ketika komponen atau subsistem yang dirancang tidak hanya banyak jumlahnya tetapi ditambah dengan multi sourcing (multi Suplier) dan sebagaimana subsistem itu bekerja. Dalam proses ini peneliti mengamati dan melakukan pengumpulan untuk suatu kebutuhan seluruh elemen sistem seperti datadata yang sudah digunakan. Dimana elemen-elemen yg dibutuhkan itu dapat menunjang dalam outsourcing management system.

\section{Analysis (Analisis Data \& Proses)}

Analisis data dan proses merupakan kumpulan dari nilai-nilai yang mencerminkan karakteristik dari individu-individu dari suatu populasi. Data bisa berupa suara, angka, gambar maupun huruf. Dari data yg sudah dikumpulkan diharapkan akan memperoleh informasi tentang populasi. Dengan hal demikian diperlukannya penguasaan dan pengetahuan metode analisis sebagai berupaya untuk membuat keluarnya informasi yang terkandung dalam data yang sudah dimiliki. Kemudian untuk tahap menganalisa kebutuhan sistem harus dilakukannya pengumpulan dengan harus berfokus pada perangkat lunak, meliputi: Sistem, Informasi, fungsi masing-masing pada bagian sistem, kerja atau cara kerja, dan antarmuka. Lalu menyajikan perangkat dan teknik yang dapat membuat peneliti untuk menentukan apa saja kebutuhan yang melalui sistem yang sudah berjalan pada rancangan outsourcing management system dalam melakukan sebuah proses pengolahan data-datanya. Perangkat yang dimaksud itu adalah pemakaian Diagram Alir Data (DAD) untuk menyusun sebuah daftar input, proses dan output fungsi bisnis.

\section{Design (Perancangan)}

Perancangan adalah suatu aktifitas yang memiliki tujuan untuk membuat atau mendesign sistem baru yang dapat menyelesaikan suatu masalah-masalah yang dihadapi perusahaan yang diperoleh dari pemilihan alternatif sistem yang terbaik. Pada tahap ini yang akan dilaksanakan dalam perancangan struktur data, arsitektur perangkat lunak, rincian prosedural, karakteristik antar muka dilaksanakan pada tahap ini. Dan dirancangnya tampilan layar seperti form masukan dan form keluaran dari sistem yang akan dirancang. 


\section{Coding (Pengkodean)}

Pengkodean adalah sebuah proses perubahan karakter data yang akan dikirim dari suatu titik ke titik lain dengan kode yang akan dikenal oleh setiap terminal yang sudah ada, dan menjadikan setiap karakter data dalam sebuah informasi digital ke dalam bentuk biner sehingga dapat ditransmisikan. Suatu terminal yang berbeda dengan menggunakan kode biner yang berbeda untuk mewakili setiap karakter. Pada tahap ini dibuat koding untuk mendapatkan apa yang ada di dalam outsourcing management system yang merupakan tahap untuk membuat suatu kode tentang software yang akan dibuat agar dapat dibaca dan diterjemahkan oleh komputer.

\section{Testing (Pengujian)}

Pengujian adalah proses yang bertujuan ingin memastikan sebuah fungsi sistem apakah semua fungsi sistem bekerja dengan baik dan mencari kesalahan yang mungkin terjadi pada sistem. Sebelum outsourcing management system digunakan dengan baik, harus dilakukan pengujian terlebih dahulu. Rangkaian pengujian ini dijalankan bersama-sama dengan data aktual dari sistem yang sudah ada atau sistem yang sedang berjalan.

\section{Implementation \& Maintenance (Implementasi \& Pemeliharaan)}

Tahap akhir dalam model waterfall, Perangkat lunak yang sudah jadi, dijalankan serta dilakukan pemeliharaan. Pemeliharaan termasuk dalam memperbaiki adanya kesalahan-kesalahan yang tidak ditemukan pada langkah-langkah sebelumnya. Perbaikan implementasi unit sistem dan peningkatan jasa sistem sebagai kebutuhan baru.

\section{HASIL DAN PEMBAHASAN}

\section{Analisis Permasalahan}

Setelah menganalisa sistem yang berjalan, maka peneliti menyimpulkan bahwa untuk mempermudah seluruh aktivitas pekerjaan penyimpanan data tenaga kerja outsourcing, selama ini perusahaan masih menggunakan dokumen. Hal ini yang mendorong peneliti untuk mencoba mengembangkan rancangan outsource management system berbasis web pada PT Sigma Cipta Utama.

\section{Diagram Konteks Sistem yang Diusulkan}

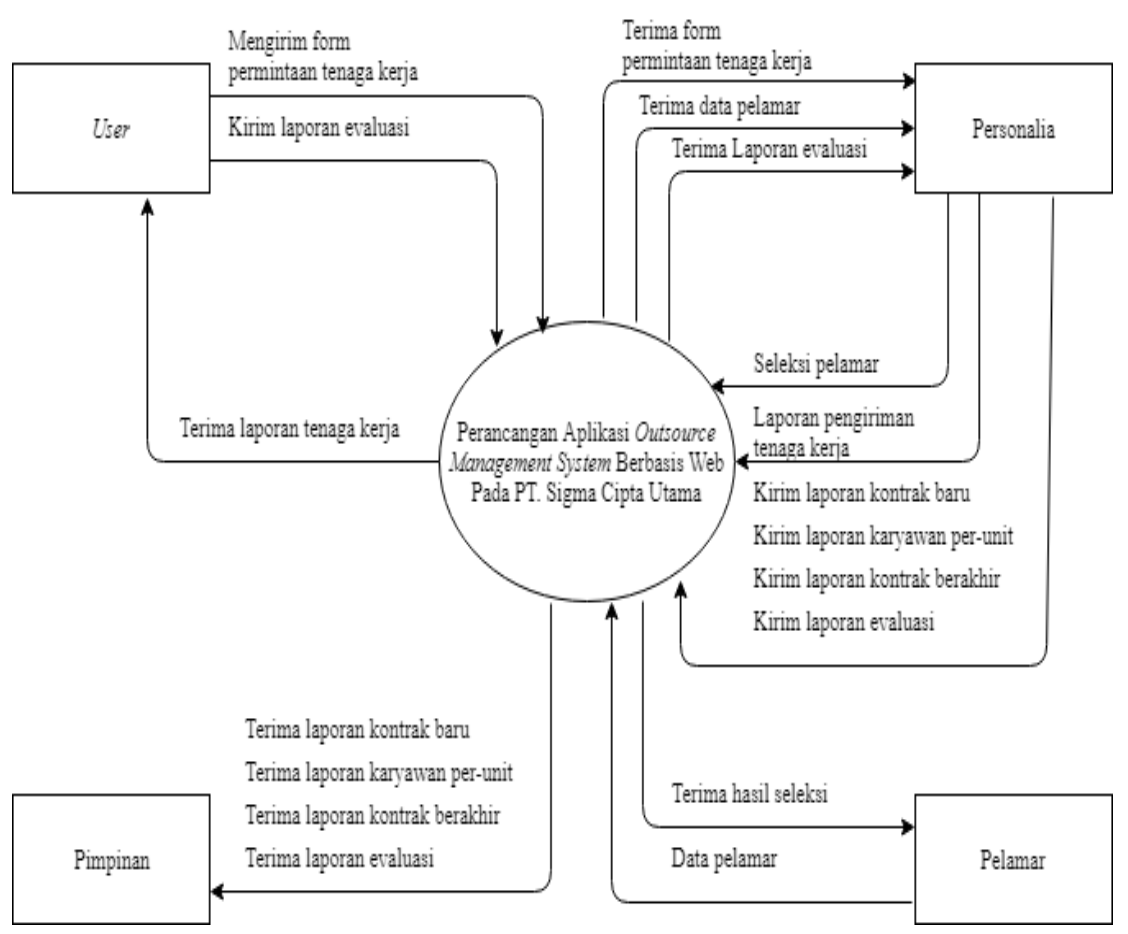

Gambar 2. Diagram Konteks Sistem yang Diusulkan 


\section{Entity Relationship Diagram (ERD)}

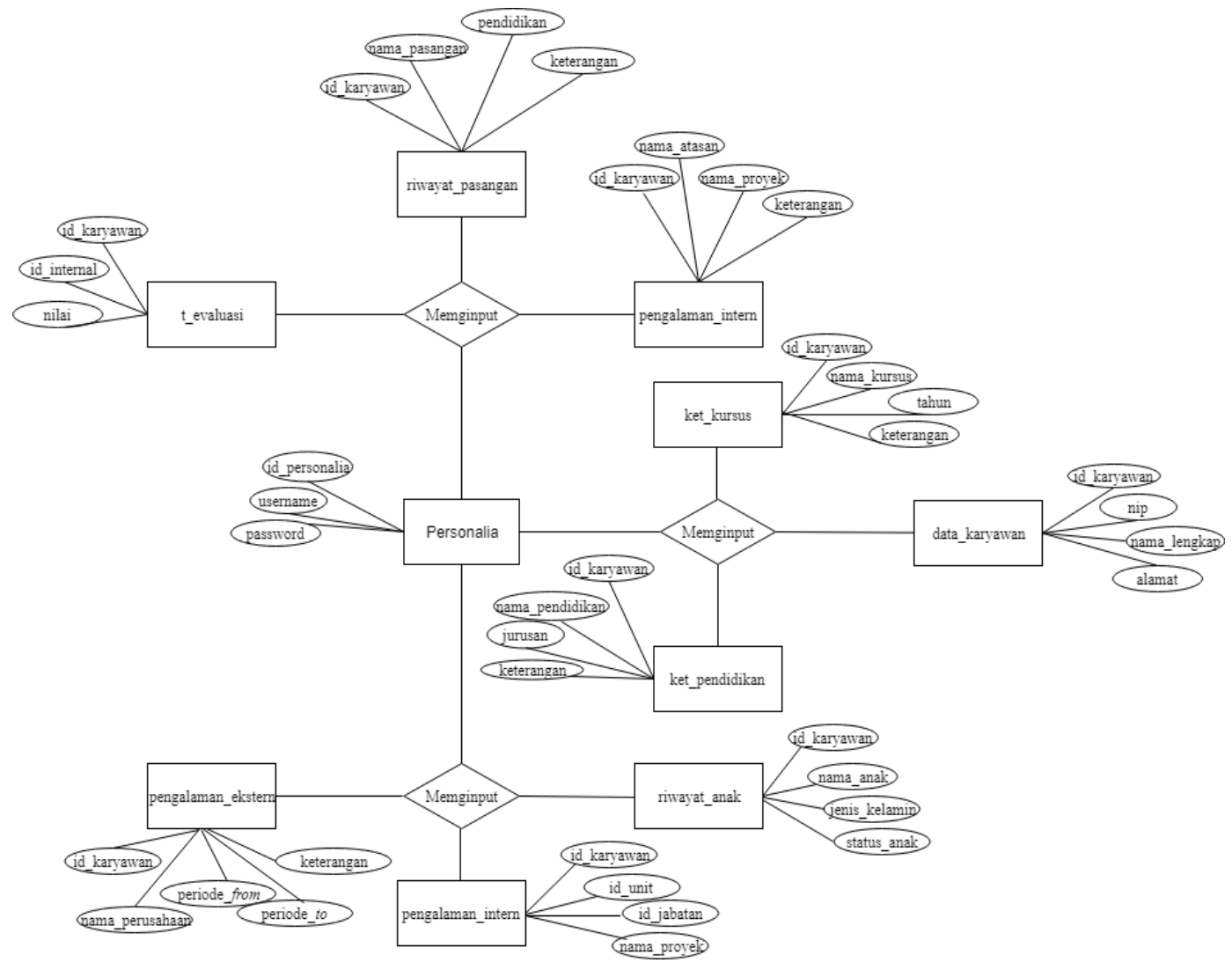

Gambar 3. Entity Relationship Diagram (ERD)

\section{Tampilan Aplikasi}

Berikut ini hasil perancangan Outsource Management System.

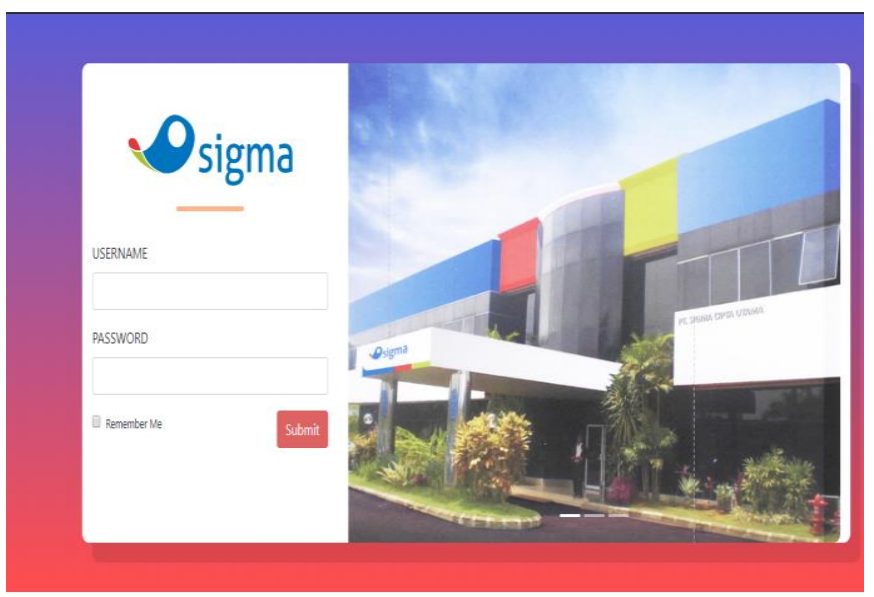

Gambar 4. Tampilan Menu Login

Pada gambar 4 diatas menampilkan form untuk login. 


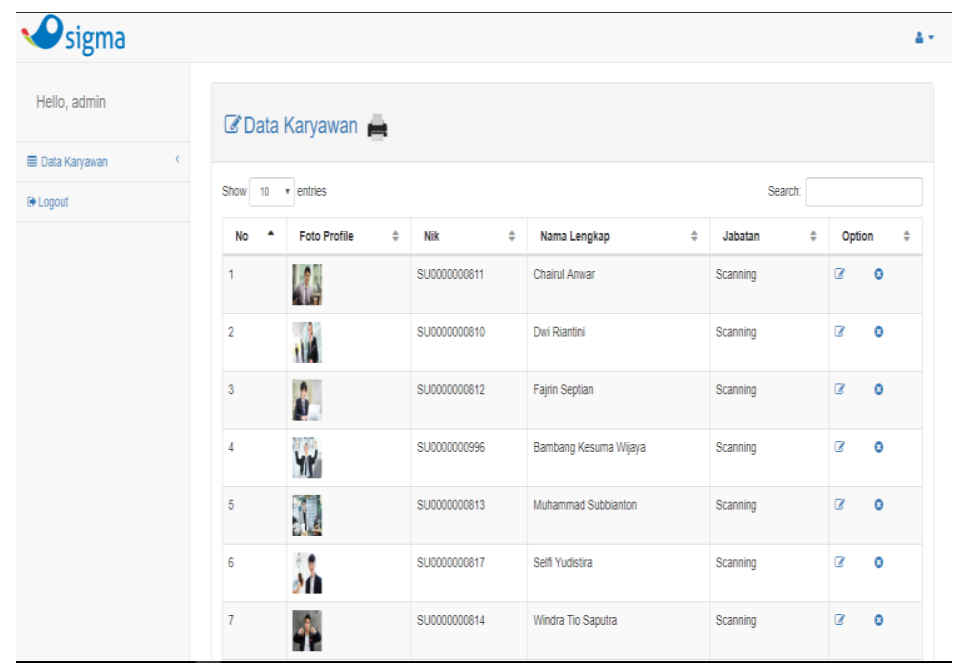

Gambar 5. Tampilan Layar Menu Utama

Pada layar ini terdapat karyawan yang masih aktif dengan jabatannya.

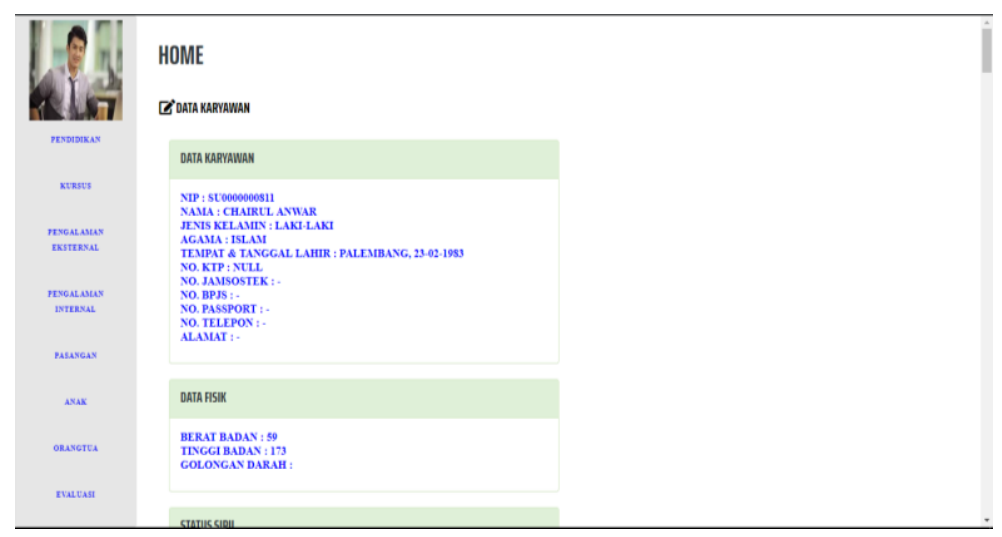

Gambar 6. Tampilan Profile Tenaga Kerja

Pada layar ini terdapat data pendidikan, data kursus, pengalaman eksternal, proyek internal, data pasangan, data anak, data orangtua, dan evaluasi.

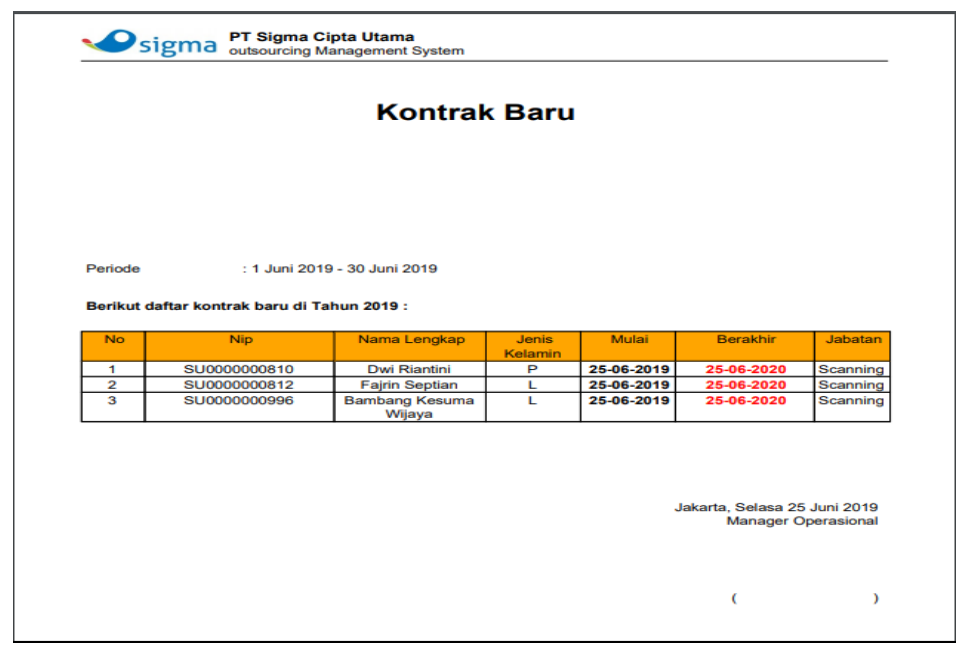

Gambar 7. Laporan Evaluasi 
Tampilan output laporan kontrak baru yang siap dicetak hasil dari data tenaga kerja yang baru masuk.

\section{SIMPULAN}

Berdasarkan analisa yang telah dilakukan peneliti, maka Perancangan Outsourcing Management System Berbasis Web (Studi kasus pada PT. Sigma Cipta Utama) yang dirancang peneliti dapat diterapkan dan merupakan salah satu solusi yang tepat bagi perusahaan ini. Sehingga dapat diambil simpulan yaitu Outsourcing Management System Berbasis Web di rancang dan di bangun menggunakan PHP 5.4.4, sistem yang berjalan manual berubah menjadi sistem komputerisasi dengan menggunakan basis data dalam pengolahan Outsourcing Management System, dengan adanya sistem laporan Outsourcing Management system tidak memungkinkan terjadinya duplikasi data dan kesalahan input serta proses pembuatan laporan tidak memerlukan waktu yang lama.

\section{DAFTAR PUSTAKA}

Diana, A., \& Setiawati, L. (2011). Pengertian sistem menurut Anastasia Diana \& Lilis Setiawati. In Sistem Informasi Akuntansi.

Indrajani, S.KOM, M. (2014). Database Systems Case Study All in One. In Database Systems Case Study All in One.

Malayu S.P Hasibuan. (2012). Manajemen Sumber Daya Manusia. In Jakarta: PT.Bumi Aksara.

Marshall B. Romney, \& Steinbart, P. J. (2003). Accounting Information Systems 9th Edition. In African Journal of Microbiology Research. https://doi.org/10.5897/AJMR12.475

Mulyadi. (2016). Pengertian sistem menurut mulyadi. In Sistem Akuntansi.

Oshri, I., Kotlarsky, J., \& Willcocks, L. (2009). The handbook of global outsourcing and offshoring. In The Handbook of Global Outsourcing and Offshoring. https://doi.org/10.1057/9780230251076

Pressman, R. S. (2010). Rekayasa Perangkat Lunak: Pendekatan Praktisi. In Software Engineering A Practitioner's Approach 7th Ed-Roger S. Pressman. https://doi.org/10.1017/CBO9781107415324.004

Sukamto, R. A., \& Shalahuddin, M. (2016). Rekayasa Perangkat Lunak (Terstruktur dan berbasis objek). Sdlc. 